\title{
Efficiency Analysis of the Sub-Saharan African small-scale Agriculture: A Review of Literature on Technical Efficiency of Maize Production
}

\author{
D Kibirige $^{1}$, M.O. Raufu ${ }^{2}$, and M.B Masuku ${ }^{3}$
}

\begin{abstract}
Increasingly, maize is becoming a staple food for many Sub-Saharan Africa (SSA) countries, and hence, it is regarded important in mitigating increasing incidences of hunger and famine in the region. This article reviews and compares literature related to farm level technical efficiency of small-scale maize production among countries of the SSA. A total of 17 studies from 11 different countries were examined. At least 2 studies related to small-scale maize farmers' technical efficiency were drawn from 6 countries, East African region being the most represented. Presentations of discussions were divided into three regions namely the West Africa, the East Africa, and the Southern Africa regions, respectively. Maize productivity in the Sub-Saharan region seem to be low, South Africa scoring only 4.37 tonnes/ha of maize far less than the potential grain yield of maize ranging between 7 tonnes/ha to 12 tonnes/ha. This prompts the region to import more grains to meet its domestic demand. The average technical efficiency (TE) index from all the studies reviewed is $70 \%$. Although South Africa as a country had the highest average score of technical efficiency index (98\%), West Africa as a region had the highest score of $82 \%$, followed by Southern Africa region with $72 \%$, and East African region scored only $57 \%$ on average. Overall technical efficiency scores suggest that there is considerable room to maximize agricultural output with the available resources and without changing the existing technologies. All reviewed studies sought to explain socioeconomic factors responsible for farm level variation in TE. Family farm labour (household size), availability of maize markets, improved seed variety, use of agro-chemical, access to farm credit, off-farm incomes and group membership were key outstanding socioeconomic factors that had a positive and significant impact on technical efficiency in the SSA region. For increased maize output and reduced budgets on maize imports, the region needs to focus and catalyse policies related to strengthening research and dissemination of technologies on maize breeding, labour saving technologies, growth in agroindustry, strengthening farmer cooperatives and maize markets, and strengthening of farmers' savings and credit facilities.
\end{abstract}

Keywords: Technical Efficiency, Maize, Sub-Saharan Africa, Small-scale farmers, productivity

\section{Introduction}

Considering world cereal acreage, output and yields, maize (Zea mays $L$.) is ranked the fifth largest in land area occupation, fourth largest in output and third largest in yield (Surinder, 2011). Maize demonstrates it key role in assuring food security as it provides about $15 \%$ and $19 \%$ of the world's protein and calories, respectively (Surinder, 2011). In Sub-Saharan African (SSA) region, maize botanically identified as is increasingly becoming one of the most important grain crops and is produced throughout the region under diverse environments. In Africa, maize is consumed directly and serves as staple diet for about 300 million people and indirectly as part of the animal feed consumed in poultry, dairy and meat products and production of ethanol as a bio-fuel and used for medical purposes (Monsanto, 2014). According to Monsanto (2014), successful maize production depends on the correct application of production inputs that will sustain the environment as well as agricultural production. However, due to low adoption of modern technologies including irrigation, maize production especially in the SSA is faced with severe droughts and high variation in weather leading to unpredictable and low yield (Monsanto, 2014).

According to the Government of Canada (2014), Sub-Saharan Africa hosts about 33 million smallholder farms responsible for $90 \%$ of food production in most countries of the region. Maize is the most important cereal crop in Sub-Saharan Africa and supports millions of smallholder farmers as source of household food and incomes (IITA, 2014). Despite the contribution of maize, millions smallholder agriculture in

\footnotetext{
${ }^{1}$ Douglas Kibirige (PhD) is a lecturer in the Department of Agricultural Economics \& management, Faculty of Agriculture at University of Swaziland.

2. M.O. Raufu (PhD) is a senior lecturer in the Department of Agricultural Economics \& Management, Faculty of Agriculture at University of Swaziland

3. Associate Professor MB Masuku is the Head of Department of Agricultural Economics \& Management, Faculty of Agriculture at University of Swaziland.
} 
Sub-Saharan Africa is faced with the highest global hunger prevalence rate (24.8\% of population) (FAO et al., 2013). The situation has been worsened by limited availability of arable land to rural small-scale farmers who are generally "resource-poor" with limited capital, cultivate on fragmented plots and insufficient access to farm inputs, low adoption of new technologies and high dependence on rainwater, and they mainly depend on family labor (Kibirige, 2013).These challenges are thought to be partly responsible for relatively low agricultural productivity in the region. Thus, the scarce resources availed to smallholder farmers need to be used in the most efficient way to maximize agricultural output including maize.

FAO (2014) data presented in Table 1 suggests that South Africa is the largest producer of maize followed by Nigeria on the African continent. To satisfy maize demand, Africa imports about $28 \%$ of the crop from beyond the continent. In terms of productivity, data presented in Table 1 indicates that in the year 2012, South Africa's yields (3.77 tons/ha) are relatively higher compared to other countries in this review, followed by Ethiopia (3.06 tons/ha), Zambia (2.65 tons/ha), Uganda (2.50 tons/ha), Malawi (2.19 tons/ha), Ghana (1.87 tons/ha), Nigeria (1.81 tons/ha), Kenya (1.67 tons/ha), Tanzania (1.24 tons/ha), Swaziland (1.09 tons/ha) and Zimbabwe (1.04 tons/ha), respectively. Results indicate that all countries are operating below the maximum potential grain yields which ranges from 7 to 12 tons/ha (Kibirige, 2013). Thus, improved productivity would help countries reduce on their import budgets of especially countries like Zimbabwe, Kenya and Swaziland with about 4,118,117 tons, 258,525 tons and 105,000 tons of maize imported in 2011. The data displayed in Table 1 suggests that these countries still have room for improved productivity may be by improving on efficient allocation of resources to maximize production at a least cost.

Table 1: Presenting the productivity of Maize in selected Sub-Saharan Africa Countries.

\begin{tabular}{|c|c|c|c|c|c|c|c|}
\hline \multirow[t]{2}{*}{ Country } & \multicolumn{4}{|l|}{2011} & \multicolumn{3}{|l|}{2012} \\
\hline & $\begin{array}{l}\text { Area } \\
\text { Harvested (ha) }\end{array}$ & $\begin{array}{l}\text { Production } \\
\text { (tons) }\end{array}$ & $\begin{array}{l}\text { Yield } \\
\text { (tons/ha) }\end{array}$ & $\begin{array}{l}\text { Imports } \\
\text { (tons) }\end{array}$ & $\begin{array}{l}\text { Area } \\
\text { Harvested(ha) }\end{array}$ & $\begin{array}{l}\text { Production } \\
\text { (tons) }\end{array}$ & $\begin{array}{l}\text { Yield } \\
\text { (tons/ha) }\end{array}$ \\
\hline Ghana & 1023177 & $168398 \quad 4$ & 1.65 & 11255 & 1042083 & 1949897 & 1.87 \\
\hline Nigeria & 6008470 & 9180270 & 1.53 & 812 & 5200000 & 9410000 & 1.81 \\
\hline Ethiopia & 2054724 & 6069413 & 2.95 & 7625 & 2013045 & 6158318 & 3.06 \\
\hline Kenya & 2131887 & 3376862 & 1.58 & 258525 & 2159322 & 3600000 & 1.67 \\
\hline Uganda & 1063000 & 2551000 & 2.40 & 17243 & 1094000 & 2734000 & 2.50 \\
\hline Tanzania & 3287850 & 4340823 & 1.32 & 11931 & 4118117 & 5104248 & 1.24 \\
\hline Malawi & 1675377 & 3699147 & 2.21 & 6106 & 1650000 & 3618699 & 2.19 \\
\hline Zambia & 1101785 & 3020380 & 2.74 & 2911 & 1074658 & 2852687 & 2.65 \\
\hline Zimbabwe & 1600000 & 1500000 & 0.94 & 459171 & 960000 & 1000000 & 1.04 \\
\hline Swaziland & 68000 & 85000 & 1.25 & 105000 & 70000 & 76000 & 1.09 \\
\hline South Africa & 2372300 & 10360000 & 4.37 & 87508 & 3141000 & 11830000 & 3.77 \\
\hline
\end{tabular}

Source: FAOSTAT (2014).

Padilla-Fernandez and Nuthall (2001) cited Farrell (1957) defining efficiency as the ability to produce a given level of output at the lowest cost. Efficiency can be divided into two concepts, the technical and allocative efficiency. Technical efficiency is the ability of the farm to produce a maximum level of output given a similar level of production inputs. Allocative efficiency literally can be defined as generating of output with the least cost of production to obtain maximum profits. Economic efficiency is a product of both allocative and technical efficiency and it is achieved when the producer combines resources in the least combination to generate maximum output as well as ensuring least cost to obtain maximum revenue (Chukwuji, et al., 2006). Therefore, for increased productivity and profitability, farmers need to improve on the management practices through trainings and transfer of knowledge and skills from less to more efficient farmers or increase on adoption of new available technologies (Padilla-Fernandez and Nuthall, 2001).

Studies reviewed in this article employed both parametric and non-parametric methods to measure technical efficiency of small-scale maize farmers. Technical efficiency can be measured using both, parametric (stochastic frontier estimation) and non-parametric (Data Envelopment Analysis (DEA)) methods. The stochastic frontier is where the deviation from the frontier is attributed to the random component reflecting measurement error and statistical noise, and an inefficiency component (Ogundele and Okoruwa, 2006). The stochastic frontier method can be a good measurement of performance because of its advantage of incorporating the random error of the regression. The random error therefore captures the effect of unimportant left out variables and errors of dependent variables as well as the farm specific inefficiencies. It provides the farm efficiency estimates with much lower variability than any other method due to the error term decomposition (Neff et al., 1994). Because of its ability to decompose errors, this method of estimation is reported to be superior to others. A widely used Cobb-Douglas production is linearized and used to estimate the technical efficiency (Stochastic frontier) and allocative efficiency (Ogundele and Okoruwa, 2006). In this review, the Stochastic Frontier was the mostly used method of determining technical efficiency of small-scale maize farmers. 
The non-parametric method of estimating efficiency includes the Data Envelopment Analysis and the Free Disposal Hull (FDH) (Kibaara, 2005). The DEA is based on the notion that a production unit employing less input than another to produce the same amount of output is more profitable. The DEA approach applies the linear programming method where a series of equations is used to construct linear production frontiers (Lemba et al., 2012). Thus, production frontier functional assumptions play less or no roles when using this method. The first DEA models were deterministic but have been modernized by including the stochastic characteristics (Khai et al., 2008). The DEA has some advantages over the parametric approaches (Speelman et al., 2007). Firstly, since it uses linear programing and constructed series of equation there is no need for assumptions set for a DEA production function. The method also gives an allowance for comparing different production frontiers in terms of a performance index. Also, efficiency estimate is not affected significantly when using small sample size. Finally, the DEA gives the freedom of determining efficiencies of the sub-vectors, for example specifying a target resource use, unlike the stochastic production frontier (Speelman et al., 2007).

\section{Empirical Studies of Technical efficiency of Sub-Saharan Country Maize Production}

In this review, Ghana and Nigeria where chosen to represent the West Africa due to scarcity of studies specifically related to technical efficiency of small-scale maize farmers in other countries within the region. Based on the data presented in Table 2, West African countries had a mean technical efficiency level of $82 \%$, and thus, only need an addition of $18 \%$ efficiency to maximize output without changing the existing technology. Ghana small-scale maize farmers were more efficient (91\% score) compared to their Nigerian counterparts who registered an efficiency levels of $71 \%$ and $83 \%$, respectively. This implies that Nigerian small-scale maize farmers have more room to maximize their output with the least combination of inputs through improved technical efficiency. Improved technical efficiency of Ghana and Nigeria with the available inputs and without changing technology may boost their productivity from 1.87 tons/ha and 1.81 tons/ha of maize, respectively to a closer result of the estimated potential grain yield ranging between 7 and 12tons/ha of maize. Further, this is expected to reduce on the countries' maize import budgets.

Table 2: Empirical Estimates of Technical Efficiency of Small-scale Maize Farming in SSA

\begin{tabular}{|c|c|c|c|c|c|c|}
\hline Author (s) & Country & $\begin{array}{l}\text { Region in the } \\
\text { Sub-Saharan } \\
\text { Africa } \\
\end{array}$ & $\begin{array}{l}\text { Empirical } \\
\text { Model }\end{array}$ & $\begin{array}{l}\text { Sample size } \\
\text { (farmers) }\end{array}$ & $\begin{array}{l}\text { Range (Min- } \\
\text { Max) of T.E } \\
\text { score }(\%)\end{array}$ & $\begin{array}{l}\text { Average T.E } \\
\text { scores }(\%)\end{array}$ \\
\hline $\begin{array}{lr}\text { Sienso G, S. } & \text { Asuming- } \\
\text { Brempong, } & \text { \&D.P.K } \\
\text { Amegashie, } 2013 & \\
\end{array}$ & Ghana & West & $\begin{array}{l}\text { Stochastic } \\
\text { Frontier } \\
\text { (SFPF) }\end{array}$ & 200 & $55-99$ & 91 \\
\hline $\begin{array}{l}\text { Nsikak-Abasi A. E \& } \quad \text { S. } \\
\text { Okon, } 2013\end{array}$ & Nigeria & West & $\begin{array}{l}\text { Stochastic } \\
\text { Frontier } \\
\text { (SFPF) } \\
\end{array}$ & 110 & $1-98$ & 71 \\
\hline $\begin{array}{l}\text { Aye GC. and ED. } \\
\text { Mungatana, 2010 }\end{array}$ & Nigeria & West & $\begin{array}{ll}\text { SFPF } \quad \& \\
\text { DEA }\end{array}$ & 240 & $43-100$ & 83 \\
\hline Average T.E-West & & & & & & 82 \\
\hline $\begin{array}{l}\text { Geta E, A. Bogale, B. } \\
\text { Kassa\& E. Elias, } 2010\end{array}$ & Ethiopia & East & DEA & 385 & $3.6-100$ & 40 \\
\hline $\begin{array}{l}\text { Alene AD \& RM Hassan, } \\
2003\end{array}$ & Ethiopia & East & $\begin{array}{l}\text { Translog } \\
\text { SFPF }\end{array}$ & 60 & $7-98$ & 76 \\
\hline $\begin{array}{l}\text { Mignouna D.B, K. Mutabazi, } \\
\text { E.M Senkondo\&V.M } \\
\text { Manyong, } 2012 \\
\end{array}$ & Kenya & East & SFPF & 600 & $21-98$ & 70 \\
\hline Kibaara BW, 2005 & Kenya & East & SFPF & 2017 & $8-98$ & 49 \\
\hline Diiro GM, 2013 & Uganda & East & SFPF & 1102 & $1-99$ & 41 \\
\hline Kibirige D, 2014 & Uganda & East & SFPF & 170 & $4-92$ & 58 \\
\hline $\begin{array}{l}\text { Msuya EE., S. Hisano \& T. } \\
\text { Nariu, } 2009\end{array}$ & Tanzania & East & SFPF & 233 & $1-91$ & 61 \\
\hline Baha M.R, 2013 & Tanzania & East & SFPF & 122 & $1-92$ & 62 \\
\hline Average T.E-East & & & & & & 57 \\
\hline ChirwaEW, 2007 & Malawi & Southern & SFPF & 156 & $8-94$ & 46 \\
\hline Tchale H., 2009 & Malawi & Southern & SFPF & 9788 & $35-88$ & 53 \\
\hline $\begin{array}{l}\text { Musaba E \& I. Bwacha, } \\
2014\end{array}$ & Zambia & Southern & SFPF & 100 & $52-93$ & 80 \\
\hline Mushunje A., 2005 & Zimbabwe & Southern & SFPF & 96 & $20-99$ & 77 \\
\hline $\begin{array}{l}\text { Dlamini S.I., MB. Masuku \& } \\
\text { J.I. Rugambisa, } 2012\end{array}$ & Swaziland & Southern & SFPF & 127 & $15-93$ & 80 \\
\hline Kibirige D, 2013 & South Africa & Southern & SFPF\& DEA & 157 & $61-100$ & 98 \\
\hline Average T.E-South & & & & & & 72 \\
\hline Overall & & & & 15663 & & 70 \\
\hline
\end{tabular}


Based on the available information, Ethiopia, Kenya, Uganda and Tanzania were considered as representatives of the East African region in this review. On average, small-scale maize farmers in East African region are only technically efficient at $57 \%$, and thus, they have room to maximum output at a least input combination without changing the existing technology, if they improve their technical efficiency by $43 \%$. Averagely, the two studies under review in Uganda provides the lowest technical efficiencies of small-scale maize farmers at $41 \%$ and $58 \%$ level, while Tanzania small-scale maize farmers on average achieved a relatively higher technical efficiency results at $61 \%$ and $62 \%$ level within the East African countries. There is an observed relatively wide gap between technical efficiency scores of the two studies under review for Ethiopia (40\% and $76 \%$ levels) and Kenya (70\% and $49 \%$ level). Those differences may be related to the geographical location of the small-scale maize farmers as these countries face a mixture of tropical cooler climate to relatively hotter semi-arid type of climate.

The national low maize productivity and the relatively lower technical efficiency of maize farmers in East Africa may partly be explained by the drought which hit hard the region between 2011 and 2012 resulting in recurring hunger (FAO et al., 2013). The most heat countries were Ethiopia and Kenya among others. Thus, to mitigate hunger, the East African countries collectively may need to step-up their productivity towards the potential grain yield of 7 to 12 tons/ha and improve on their technical efficiency by about $43 \%$ level. Further, improved productivity and technical efficiency is thought to reduce on the maize import budgets, and these funds could be allocated elsewhere within the economy.

Malawi, Zambia, Zimbabwe, Swaziland and South Africa were considered as representative of the Southern African region under review. Data presented in Table 2 indicate that small-scale maize farmers in South Africa had the highest technical efficiency score of $98 \%$ level, followed by Swaziland and Zambia each scoring $80 \%$ level, Zimbabwe (77\% level) and lastly Malawi whose farmers could only attain an overall average of about 50\% technical efficiency level. Averagely, Southern African small-scale maize farmers were operating at $72 \%$ technical efficiency level indicating that they had room to expand their maize output with a least input combination and without changing the existing technology by improving their technical efficiency by $28 \%$. South Africa's relatively high technical efficiency of small-scale maize farmers could be explained by the fact that most production is done on small-irrigation schemes or homestead food gardening irrigation system. Swaziland performance could be explained by anticipating technological trans-boarder transfer from the neighbouring South Africa. Like other regions under review, Southern Africa region should step-up their technical efficiency to realise increased output and reduced maize import budgets.

\section{Socio-Economic Factors Related to Technical Efficiency of Maize Farmers in SSA}

For West Africa, as expected, factors found to have a positive and significant impact of small-scale maize farmers' technical efficiency in the three studies under review included improved variety of maize seed, distance from home to farm, land size, labour, inorganic fertilizers, timely and availability of planting materials, access to credit, access to market, age and education level of farmer, household size, and group membership (Table 3.1). With exception of land size and age of farmers which had mixed impact (- or + ), a unit increase in any of these factors would improve on the technical efficiency of small-scale maize farmers in West Africa, and hence this is thought to increase output and reduce on maize importation budgets of the countries.

Table 3.1: Socio-Economic Factors Related to Technical Efficiency of Small-scale Maize Farming in West Africa

\begin{tabular}{|l|l|l|l|l|}
\hline Author & Country & Region & T.E Average & Socio-Economic Factors \\
\hline $\begin{array}{l}\text { Sienso G, S. Asuming-Brempong, } \\
\text { \&D.P.K Amegashie, 2013 }\end{array}$ & Ghana & West & 91 & $\begin{array}{l}\text { Improved Variety, [Gender], [Experience] Distance } \\
\text { from home to farm, \& [Extension] }\end{array}$ \\
\hline $\begin{array}{l}\text { Nsikak-Abasi A. E \& S. Okon, } \\
2013\end{array}$ & Nigeria & West & 71 & $\begin{array}{l}\text { Land size, labour, inorganic fertilizer, planting } \\
\text { materials, [age], [technical assistance], credit, \& } \\
\text { market }\end{array}$ \\
\hline Aye GC. and ED. Mungatana, 2010 & Nigeria & West & 83 & $\begin{array}{l}\text { Age, Education, Household size, [land size],Group } \\
\text { Membership, [extension], Credit, Market, improved } \\
\text { seed variety }\end{array}$ \\
\hline
\end{tabular}

Surprisingly, all studies under review for West African Countries indicate a negative relationship between small-scale maize farmers' technical efficiency and Extension/technical assistance. One would expect that increase in farmers' access to extension services/technical assistance would increase their efficiency in maize production, but rather results in the model indicate that increase in farmers' access to input use training leads to a decrease in the technical efficiency. The negative relationship between access to extension services and technical efficiency may be as a result of poor quality extension services rendered to farmers due to technically unqualified extension staff or farmers do not put to practice what is being taught by extension officers (Awoniyi et al., 2007; and Kodua-Agyekum, 2009; Kibirige, 2013). 
Mixed results on the impact of socioeconomic factors of East African small-scale farmers on technical efficiency of maize production were observed across studies under review. In all studies under review where improved maize seed variety was considered among the independent variables possessed a positive and significant impact on technical efficiency. To some extent also household size in most studies under review had a positive and significant impact on farmers' technical efficiency. Results under review suggest that generally improved varieties and family labour are very important in improving technical efficiency of most small-scale maize farmers in East Africa. In Ethiopia, with exception of agro-ecology, oxen holding, and improved seed variety which had a positive and significant impact on technical efficiency, factors like education, access to credit, and timely availability of inputs had a negative and significant influence on technical efficiency. Farm size possessed mixed results of positive or negative (+/-) relationship with technical efficiency of maize farmers in Ethiopia. Therefore, to improve on technical efficiency among small-scale farmers in Ethiopia policy makers need to consider the agro-ecological zoning, promote use of oxen and improved seed varieties.

Table 4: Socio-Economic Factors Related to Technical Efficiency of Small-scale Maize Farming in East

\begin{tabular}{|l|l|l|l|l|}
\hline Author & Country & Region & T.E Average & Socio-Economic Factors \\
\hline $\begin{array}{l}\text { Geta E, A. Bogale, B. Kassa\& E. } \\
\text { Elias, 2010 }\end{array}$ & Ethiopia & East & 40 & $\begin{array}{l}\text { agro-ecology, oxen holding, farm size \& improved } \\
\text { seed varieties }\end{array}$ \\
\hline Alene AD \& RM Hassan, 2003 & Ethiopia & East & 76 & $\begin{array}{l}\text { [farm size], [education], [credit] \& [timely } \\
\text { availability of inputs] }\end{array}$ \\
\hline $\begin{array}{l}\text { Mignouna D.B, K. Mutabazi, E.M } \\
\text { Senkondo\&V.MManyong, 2012 }\end{array}$ & Kenya & East & 70 & $\begin{array}{l}\text { Improved maize variety, [farm size] } \\
\text { [household size] }\end{array}$ \\
\hline Kibaara BW, 2005 & Kenya & East & 49 & $\begin{array}{l}\text { education [age] [health] [gender] } \\
\text { [tractor use] \& [off-farm income] }\end{array}$ \\
\hline $\begin{array}{l}\text { Diiro GM, 2013 } \\
\text { Kibirige D, 2014 }\end{array}$ & Uganda & East & 41 & $\begin{array}{l}\text { Group membership, household size, spouse } \\
\text { drought], year of production \& location of farmer } \\
\text { education, spouse major occupation, improved } \\
\text { seeds, [Market] }\end{array}$ \\
\hline $\begin{array}{l}\text { Msuya EE., SHisano\& T. Nariu, } \\
2009\end{array}$ & Tanzania & East & 61 & $\begin{array}{l}\text { Hand hoe, off-farm income, [education], } \\
\text { [extension], [land fragmentation], [capita], [input } \\
\text { prices], [availability of inputs], [agrochemicals] }\end{array}$ \\
\hline Baha M.R, 2013 & & 58 & $\begin{array}{l}\text { Household size, [farm size], distance from home to } \\
\text { farm, gender, [Extension], credit, fertilizer, } \\
\text { fansecticide \& [hand hoe] }\end{array}$ \\
\hline
\end{tabular}

For Kenya's case, small-scale maize farmers using improved maize seed variety with a higher education level, hold smaller farm size with smaller household size, younger, using less of tractors, and earn less off-farm income are more likely to be technically efficient. Uganda's small-scale maize farmers' household size, year of production, location, group membership, improved maize seeds variety, and spouse's education level and major occupation had a positive and significant impact on technical efficiency. Small-scale farmers' gender, farm size, severe drought and market (mainly selling at farm-gate) had a negative and significant impact on technical efficiency of maize production. Technically efficient small-scale maize farmers in Tanzania are more likely to be earning more off-farm income with a large household size and stay far away from the farm and have access to credit. Use of hand hoe and agrochemicals presented mixed results in regards to the relationship between farmers' socioeconomic factors and technical efficiency.

In one of the Tanzanian study under review (Msuya EE., S Hisano and T. Nariu, 2009), use of hand hoe had a positive and significant on technical efficiency, while the same factor had a negative and significant impact on technical efficiency in another study by Baha (2013). Use of insecticide alone as an agrochemical had a positive and significant impact on technical efficiency, while agrochemical use in maize production in another study had a negative and significant impact on technical efficiency. Surprisingly, extension, education, availability of capital and inputs had a negative impact on technical efficiency yet are perceived to have a positive impact. This may be due to poor dissemination of extension information, more educated farmers resort to formal jobs, more capital invested in other enterprises other than maize, and improper use of farm inputs, respectively, and hence, resulting in this negative relationship. Farm size, land fragmentation, and input prices among small-scale maize farmers in Tanzania also had a negative and significant impact on technical efficiency of maize production.

Based on studies under review in this article, generally, the positive and significant drivers of technical efficiency among small-scale maize farmers in Southern Africa include age of farmer, market availability, access to inputs and farm credit, use of agro-chemicals, group membership, household size, farming experience and off-farm incomes, gross margins, and commercialisation level (out marketed/total output harvested). More than one study under review suggest that factors like use of improved seed variety, education, extension and 
training on use of inputs, and farm size had a negative and significant impact on small-scale maize farmers in Southern Africa. This may be due to lack of techniques of using improved seeds or the technology comes with lots of costs of other agro-chemical to realise maximum efficiency yet farmers are poor to meet these costs. These costs may also apply to farmers who want to expand farm size and yet they can hardly meet extra costs, which cannot be even met by their marketable surplus, thus, they tend to use lesser inputs than recommended and hence compromising efficiency.

Other factors identified to have a positive and significant impact on small-scale maize farmers' technical efficiency included hired labour and intercropping, while crop rotation practice and distances to the market had a negative and significant impact on the same. Hired labour may improve on shared knowledge, and intercropping may increase chances of pest/disease and weed control or improved nitrogen fixing by legumes, and hence improving on efficiency, while crop rotation may compromise the soil nutrition and hampering of the learning process, and distance to markets may discourage efforts of farmers to maximize the marketable surplus.

Table 5: Socio-Economic Factors Related to Technical Efficiency of Small-scale Maize Farming in Southern Africa

\begin{tabular}{|c|c|c|c|c|}
\hline Author & Country & Region & T.E Average & Socio-Economic Factors \\
\hline Chirwa EW, 2007 & Malawi & Southern & 46 & [group membership], [hybrid seeds] \\
\hline TCHALEH.,2009 & Malawi & Southern & 53 & $\begin{array}{l}\text { Age, land tenure, [Land], Education, market } \\
\text { availability, [distance to markets], access to inputs, } \\
\text { access to farmer credit, group membership, } \\
\text { extension, household size \& hired labour. }\end{array}$ \\
\hline Musaba E\& I. Bwacha, 2014 & Zambia & Southern & 80 & $\begin{array}{l}\text { age of farmer, cooperative membership, and farm } \\
\text { size, [seed types used, rotation practices, and } \\
\text { education level] }\end{array}$ \\
\hline Mushunje, 2005 & Zimbabwe & Southern & 77 & [farm size], Household size, [age] [education] \\
\hline $\begin{array}{l}\text { Dlamini S.I., MB. Masuku \& } \\
\text { J. I. Rugambisa, } 2012\end{array}$ & Swaziland & Southern & 80 & $\begin{array}{l}\text { Farmers' age, off-farm income, farmers' } \\
\text { experience, intercropping, \& [type of seeds]. }\end{array}$ \\
\hline Kibirige D, 2013 & South Africa & Southern & 98 & $\begin{array}{l}\text { Household size, experience, [farm size, training on } \\
\text { use of inputs], use of agro-chemicals, gross } \\
\text { margins, commercialization level, \& off-farm } \\
\text { incomes. }\end{array}$ \\
\hline
\end{tabular}

\section{Summary and Concluding Comments}

A total of 17 studies related to small-scale maize farmers' technical efficiency estimation using farm level data from 11 different Sub-Saharan African countries were reviewed. Countries that received more attention in this review included Nigeria, Ethiopia, Kenya, Uganda and Tanzania accounting for two studies in each. These studies were divided into three groups based on their location on the African continent including West Africa represented by Nigeria and Ghana, East Africa represented by Ethiopia, Kenya, Uganda and Tanzania, and the Southern Africa represented by Malawi, Zambia, Zimbabwe, Swaziland and the Republic of South Africa.

Aggregated data from FAO (2014) indicate that maize productivity in the Sub-Saharan Africa region is still recorded low, South Africa scoring the highest productivity of 4.37 tonnes/ha of maize far below the potential grain yield which ranges between 7 and 12 tonnes/ha. Although there is a high variation, the overall technical efficiency of small-scale farmers' maize production ranged between 1 and $100 \%$ with a total average of $70 \%$. Based on calculated average technical efficiency scores from each region presented in this article, West African region small-scale maize farmers exhibited a higher technical efficiency score of $82 \%$, followed by Southern Africa region with $72 \%$ technical efficiency score, and East African region with the least technical scores of 57\%. By country, South African small-scale maize farmers had the highest technical efficiency score of $98 \%$ followed by Ghanaian farmers with $91 \%$ efficiency score. South African farmers' higher technical efficiency is mainly attributed to cultivation on irrigation schemes. Generally, these results suggest a major conclusion that small-scale maize farmers in the Sub-Saharan Region have considerable room to increase maize output without changing the existing technologies.

Attention should be put on the socioeconomic factors that significantly affect technical efficiency of small-scale farmers for increased maize output in the Sub-Saharan region. Family farm labour (household size), availability of maize markets, improved seed variant, use of agro-chemical, access to farm credit, off-farm incomes and group membership are important factors that played a vital role of improving maize production efficiency among small-scale farmers in Sub-Saharan Africa. Based on reviewed findings, it can be recommended that given the scarce resources faced by small-scale farmers the public and the private sector should join hands to strengthen the research and innovation centres to develop more affordable and improved maize seed varieties. Furthermore, reviewed articles suggest more investment in agro-chemical industries and bringing closer agro-input markets to farmers. Venture in labour saving technologies could be an alternative to family farm labour and the surplus labour can be used to earn more off-farm income to support the farm 
business. Farmers groups, associations and cooperatives still play a vital role in farm production and should be given attention. These cooperatives are a source of information, shared farm-inputs, collective marketing, improved bargaining power, and enhance social cohesion. Through cooperatives, establishment of savings and credit entities should be encouraged.

Since maize production is increasingly becoming a major staple food for most Sub-Saharan Africa, intervention that seek to boost maize output would address challenges related to hunger, malnutrition, food insecurity, poor quality of labour, stagnant rural economic growth, unemployment, household income inequalities and the widespread rural household poverty levels.

\section{References:}

[1]. Alene AD \& RM Hassan, 2003: "The determinants of farm-level technical Efficiency among adopters of improved maize production technology in Western Ethiopia.” Agrekon, Vol 42, No 1 (March 2003).

[2]. Awoniyi, A Olubukola, Omonona, T Bolarin, 2007, "Production Efficiency In Yam Based Enterprises In Ekiti State, Nigeria", Journal of Central European Agriculture Vol 7 (2006) No 4.

[3]. Aye GC. and ED. Mungatana, 2010, "Technical efficiency of traditional and hybrid maize farmers in Nigeria: Comparison of alternative approaches.": Department of Agricultural Economics, Extension and Rural Development, University of Pretoria, South Africa: African Journal of Agricultural Research Vol. 5(21), pp. 2909-2917, 4 November, 2010.

[4]. Baha M.R, 2013, "Sources of Technical Efficiency Among Smallholder Maize Farmers in Babati District, Tanzania." School of Business Studies and Economics, University of Dodoma, Tanzania: International Journal of African and Asian Studies - An Open Access International Journal Vol.1 2013.

[5]. Chirwa EW, 2007: "Sources of Technical Efficiency among Smallholder Maize Farmers in Southern Malawi." Department of Economics: Chancellor College, University of Malawi: AERC Research Paper 172 African Economic Research Consortium, Nairobi -November 2007.

[6]. Chukwuji C. O., O. E Inoni, O. D Ogisi, and W. J Oyaide, 2006, "A Quantitative Determination of Allocative Efficiency in Broiler Production in Delta State, Nigeria", Department of Agricultural Economics and Extension, Delta State University, Asaba Campus, Asaba. Delta State, Nigeria: Agriculturae Conspectus Scientifi cus, Vol. 71 (2006) No. 1 (21-26).

[7]. Diiro GM, 2013, "Impact of Off-farm Income on Agricultural Technology Adoption Intensity and Productivity- Evidence from Rural Maize Farmers in Uganda.": Uganda Strategic program-IFPRI: Working Paper 11 -January 2013.

[8]. Dlamini S.I., MB. Masuku and J. I. Rugambisa, 2012: "Technical efficiency of maize production in Swaziland: A stochastic frontier approach.” : African Journal of Agricultural Research Vol. 7(42), pp. 5628-5636, 2 November, 2012: DOI: 10.5897/AJAR12.1204: ISSN 1991-637X @ 2012 Academic Journals

[9]. Food and Agriculture Organization of the United Nations (2012): FAOSTAT: Production-Crops: Updated: 07 February 2014:http://faostat.fao.org/site/567/DesktopDefaultaspx? PageID=567\#ancor.

[10]. FAO, IFAD and WFP. 2013. The State of Food Insecurity in the World 2013. The multiple dimensions of food security. Rome, FAO.

[11]. Geta E, A. Bogale, B. Kassa\& E. Elias, 2010: "Productivity and efficiency analysis of smallholder maize producers in Southern Ethiopia.” Department of Agricultural Economics, Haramaya University, Ethiopia: Kamla-Raj 2013: J Hum Ecol, 41(1): 67-75 (2013)

[12]. Government of Canada (Foreign Affairs, Trade and Development), 2014: "Canada is helping to improve the Livelihoods of SmallScale African farmers": Access online on 10/06/2014; http://www.international.gc.ca/media/dev/news-communiques/2014/05/03 a.aspx? lang=eng.

[13]. IITA, 2014: "Maize Crop-IITA.": Accessed online on 10/06/2014: webpage: http://www.iita.org/maize.

[14]. Khai H V., M. Yabe, H. Yokogawa and G. Sato, 2008, “ Analysis of Productive Efficiency of Soybean Production in the Mekong River Delta of Viet Nam”, J. Fac. Agr., Kyushu Univ., 53 (1), 271-279 (2008).

[15]. Kibaara W. B., 2005, "Technical efficiency in Kenyan's maize production: An application of the Stochastic Frontier Approach", Master's Thesis, Department of Agricultural and Resource Economics Colorado State University Fort Collins, Colorado: USA.

[16]. Kibirige D., 2013, "The Impact of Human Dimensions on Smallholder Farming in the Eastern Cape Province of South Africa", PhD thesis, University of Fort Hare, Alice Campus, South Africa

[17]. Kibirige D, 2014, "Estimation of Technical Efficiency among Smallholder Maize Farmers in Uganda: A Case Study of Masindi District of Uganda." Department of Agricultural Economics and Management, Faculty of Agriculture, University of Swaziland, Luyengo, Swaziland. International Journal of Economics, Commerce and Management, United Kingdom: Vol. II, Issue 5, 2014: ISSN 23480386.

[18]. Kodua-Agyekum C., 2009, "The transfer of technology to the rural poor: The case of Qamata Irrigation Scheme in the Eastern Cape Province of South Africa". Phd Thesis, Faculty of Humanities, Development and Social Sciences, University of Kwazulu-Natal, South Africa.

[19]. Lemba J., M. D'Haese, L. D'Haese, A. Frija and S. Speelman, 2012, "Comparing the technical efficiency of farms benefiting from different agricultural interventions in Kenya's drylands", Development Southern Africa, 29:2, 287-301, Publisher: Routledge.

[20]. Mignouna D.B, K. Mutabazi, E.M Senkondo\&V.MManyong, 2012: "Assessing the technical efficiency of maize producers with Imazapyr-Resistant Maize for Striga control in Western Kenya." Journal of Development and Agricultural Economics Vol. 4(8), pp. 245-251, 12 May, 2012. DOI: 10.5897/JDAE12.021: ISSN 2006-9774 @2012 Academic Journals.

[21]. Monsanto 2014: "Water Efficient Maize for Africa (WEMA): Improved Maize Varieties to Aid Farmers in Sub-Saharan Africa". (http://www.monsanto.com /improving agriculture/ pages/water-efficient-maize-for-africa.aspx) accessed online: Date: 10th June2014.

[22]. Msuya EE., S Hisano and T. Nariu, 2009, "Explaining Productivity Variation among Smallholder Maize Farmers in Tanzania.”: Kyoto University: MPRA Paper No. 14626, posted 13. April 2009 08:51 UTC.

[23]. Musaba E and I. Bwacha, 2014: Technical Efficiency of Small Scale Maize Production in Masaiti District, Zambia: A Stochastic Frontier Approach: Journal of Economics and Sustainable Development: Vol.5, No.4, 2014. ISSN 2222-1700 (Paper) ISSN 22222855 (Online).

[24]. Mushunje A., 2005: "Farm efficiency and land reform in Zimbabwe." PhD thesis: Department of agricultural economics and extension, University of fort hare, Alice, South Africa April 2005. 
[25]. Nsikak-Abasi A. E and S. Okon, 2013: "Sources of technical efficiency among subsistence maize farmers in Uyo, Nigeria." Department of Agricultural Economics and Extension, University of Uyo, P.M.B. 1017, Uyo, Akwa Ibom State, Nigeria: Discourse Journal of Agriculture and Food Sciences: Vol. 1(4), pp. 48-53, April 2013.

[26]. Ogundele O. O and O. V. Okoruwa, 2006, "Techical efficiency differential in rice production technologies in Nigeria", Africa Research Consortium, Research paper 154.

[27]. Padilla-Fernandez M. D. and P. Nuthall, 2001, Farmers' goals and efficiency in the production of sugar cane: The Philippine case, Farm and Horticultural Management Group Lincoln University, ISSN 1174-8796, Research Report 07/2001.

[28]. Sienso G, S. Asuming-Brempong, \&D.P.K Amegashie, 2013: "Estimating the efficiency of maize farmers in Ghana." Contributed Paper prepared for presentation at the 4th International Conference of the AAAE, Cape Town, Hammamet, Tunisia, $22-25$ September, 2013.

[29]. Speelman S., M. D’Haese, J. Buysse, , and L. D’Haese, 2007, “ Technical efficiency of water use and its determinants study at smallscale irrigation schemes in North-West Province, South Africa", Paper prepared for presentation at the $106^{\text {th }}$ seminar of the EAAE; Pro-poor development in low income countries: Food, agriculture, trade, and environment; 25-27 October 2007 Montpellier, France.

[30]. Surinder Chugh, 2011: "Project Feasibility Report on Maize Processing in Himachal Pradesh- Surinder": Surinder chugh (Roll Number: 25) EPDGCFM 2010 - 12.

[31]. Tchale H., 2009: "The efficiency of smallholder agriculture in Malawi.": World Bank, Lilongwe, Malawi: AFJARE Vol 3 No 2 September 2009 